\title{
The Role of Land Ownership and Non-Farm Livelihoods on Household Food and Nutrition Security in Rural India
}

\author{
Loan $\mathrm{Vu}^{1}$, Anu Rammohan ${ }^{2}$ and Srinivas Goli ${ }^{3, *(D)}$ \\ 1 Bankwest Curtin Economics Centre, Curtin University, Perth, WA 6102, Australia; lili.loanvu@curtin.edu.au \\ 2 Department of Economics, University of Western Australia, Perth, WA 6009, Australia; \\ anu.rammohan@uwa.edu.au \\ 3 Australia India Institute, University of Western Australia, Perth, WA 6009, Australia \\ * Correspondence: srinivas.goli@uwa.edu.au; Tel.: +61-416271232
}

check for updates

Citation: Vu, L.; Rammohan, A.; Goli, S. The Role of Land Ownership and Non-Farm Livelihoods on Household Food and Nutrition Security in Rural India. Sustainability 2021, 13, 13615. https://doi.org/ $10.3390 /$ su132413615

Academic Editor: Hossein Azadi

Received: 8 November 2021

Accepted: 2 December 2021

Published: 9 December 2021

Publisher's Note: MDPI stays neutral with regard to jurisdictional claims in published maps and institutional affiliations.

Copyright: (c) 2021 by the authors. Licensee MDPI, Basel, Switzerland. This article is an open access article distributed under the terms and conditions of the Creative Commons Attribution (CC BY) license (https:// creativecommons.org/licenses/by/ $4.0 /)$.

\begin{abstract}
South Asia remains the region with the highest prevalence of undernourishment with India accounting for 255 million food insecure people. A worsening of child nutritional outcomes has been observed in many Indian states recently and children in rural areas have poorer nutrition compared to those in urban areas. This paper investigates the relationship between land ownership, non-farm livelihoods, food security, and child nutrition in rural India, using the Young Lives Survey. The survey covers the same rural households and children over the period 2002-2013 in the states of Andhra Pradesh and Telangana. Our empirical analysis uses a sample of 1209 children (and their households) who were aged around 1 year in 2002. Our results show that large agricultural land ownership is significantly associated with better child nutrition (measured using height-for-age and stunting) and household food security. A transition from farm to non-farm work improves child nutrition, but only among landless households. While access to land is still critical for improving household food and nutrition security among rural households, there is a trend towards greater non-farm livelihoods, and a decline in reliance on farming, particularly among landless and marginal farmers.
\end{abstract}

Keywords: food security; child nutrition; rural households; India

\section{Introduction}

The State of Food Security and Nutrition in the World 2020 report has highlighted the critical role of a diverse diet to prevent malnutrition, the need to improve the nutrient adequacy of diets, and the transformation of food systems to support affordable healthy diets. However, the cost of a healthy diet currently exceeds national average food expenditures in most developing countries [1]. Despite great progress, South Asia remains the region with the highest prevalence of undernourishment [2], with India the largest country in the region accounting for 255 million food insecure people.

In India, nutritional outcomes are generally worse in rural areas where agriculture is the predominant occupation of nearly two-thirds of the rural labor force [3-5]. In these settings, income from land often accounts for a substantial proportion of household income, with income generation and diversification of livelihoods critically dependent on asset ownership [6]. Land is regarded as a valuable asset that the owner can mortgage to access credit or sell for cash when they face economic shocks [6,7].

However, three-quarters of rural households in India are either landless or only have access to marginal land [8]. Furthermore, farming households are significantly reliant on rainfall for agricultural production and face difficulty in accessing markets for agricultural inputs and outputs $[9,10]$. The small size of agricultural land also constrains food production [11,12], making it difficult for small farmers to meet their food consumption needs through own-production [4]. A majority of agricultural land in India is privately owned, and transferred inter-generationally, which makes land ownership per capita smaller with each successive generation [13]. 
Non-farm activities have therefore become increasingly important source of livelihood for rural households, with non-farm income now making up approximately half of total farm household's income $[10,14,15]$. This suggests that rural households in India may have become increasingly less reliant on land and agricultural livelihoods. This phenomenon is widely observed not just among small landholding households but also in medium and large-farming households [16-18].

However, the role of non-farm livelihoods on food and nutrition security is empirically ambiguous in India. The question assumes importance at a time when unemployment levels, rural distress in India is high $[3,15]$. Data from early estimates of India's National Family Health Survey-5 (NFHS-5) 2019-21 paint a poor picture of child malnutrition with child stunting having worsened (stagnated) in 10 (8) out of 22 Indian states, wasting and underweight increased in 11 out of 22 and overweight increased in 16 and only 1 state has seen a decline in child overweight [19].

Against this background, our paper addresses the links between household land, livelihoods, food security, and child nutrition outcomes over the period 2002-2013 using a sample of 1209 children who were aged around 1 year in 2002. Our analysis firstly can contribute to the literature on household livelihoods and child nutrition security. While the relationships between access to land and food security at the household level is widely studied, the role of household non-farm livelihoods in influencing food and nutrition security is under-researched.

Secondly, our analyses draw on four waves of the Young Lives Survey, a unique panel dataset covering approximately 1209 young children and their households from 2002 to 2013, in the states of Andhra Pradesh and Telangana in India. Our analysis is able to link household's land access, livelihoods, and food security to child nutritional outcomes for the same households and children over an eleven-year period. To the best of our knowledge, ours is the first paper to do so using a panel dataset. This is an important complement to existing cross-sectional data as it can account for unobserved heterogeneity across individuals, which is likely to have a large influence on both livelihoods and nutrition.

\section{Literature Review}

Global evidence shows that the relationship between land, food, and nutrition security is mixed. Households with large landholdings have greater access to food in Myanmar [7,18], and have better child nutritional outcomes in Bangladesh [20]. On the other hand, ownership of agricultural land had no influence on child nutrition status in Nepal [21].

Previous research shows that non-farm income improved food consumption and dietary diversity in Nigeria [22], Northern Ghana [23], Tanzania [24], and has positive effects on child anthropometry in Ethiopia [25].

Although farming households are also dependent on markets for food consumption, prices of purchased food are often higher than own-produced food due to costs of storage, transportation, and distribution. In some poor and remote areas in India, households still mainly consume their own-produced food due to the non-availability or difficult accessibility to markets $[26,27]$.

Both D'Souza et al.'s [14] and Rahman and Mishra's [27] study using panel data from the Indian Human Development Survey (IHDS) show that non-farm livelihoods are positively associated with household food and nutrition security. They find that households involved in non-farm activities are more likely to have higher food expenditure, especially on non-cereal items and greater dietary diversity.

Studies using Young Lives Survey dataset such as Humphries et al. [28], Humphries et al. [29], and Singh et al. [30], also analyze the relationship between food security and child stunting. However, their study differs from ours in several respects. Both Humphries et al. [28] and Humphries et al. [29] make multi-country comparison of child stunting and food security and household expenditure, respectively, but they do not incorporate the role of land ownership and the agricultural households. Moreover, they focus on older children aged 5 years in 2006 and 8 years in 2009. Similarly, Singh et al. [30] study the influence 
of the midday meal scheme program (a food supplement program implemented among school-age children) on child stunting, comparing children between 2002 and 2006. Our study, on the other hand, focuses on the nexus between land ownership, food security, and child stunting, taking into account four waves of the survey $(2002,2006,2009$, and 2013), and focusing on children aged 1 year in 2002.

It is critical to understand how these changes to rural livelihoods interact with household food and nutrition security. However, a clear understanding of the linkages between land ownership, livelihood diversification, and household food and nutrition security is lacking due to the absence of panel data. By using the unique Young Lives Survey panel dataset, our study seeks to address this research gap.

\section{Data and Methodology}

The data for our analyses come from four rounds of the Young Lives Survey in India. The Young Lives Survey has been conducted repeatedly among the same children since 2002 with the aim of investigating childhood poverty among approximately 12,000 children [31]. In India, the survey was conducted in 2002, 2006, 2009, 2013, and 2016 in the states of Andhra Pradesh and Telangana-in which the surveyed districts were identified by a ranking based on a number of criteria related to the development of economy, human resources, and infrastructure. There were 20 surveyed sites in three different agro-climatic areas including Coastal Andhra, Rayalseema, and Telangana. In each site, 100 children aged around one (classified as a younger cohort), and 50 children aged around eight (classified as an older cohort) in 2002 were randomly selected, with one child per household. The data includes detailed information on child anthropometric outcomes that potentially provide more reliable and more accurate measures of food and nutrition security compared to other self-reported measures. Additionally, the data also includes a wide range of information on the socio-economic and demographic profiles of the children's households, in particular access to land, livelihoods, and other socio-economic characteristics.

The surveys follow around 1209 younger-cohort children, who were on average around 1 year old at the time of the first round in 2002, and 1000 older cohort children, who were about 8 years old in 2002. We focus on the younger cohort due to a greater availability of their anthropometric information. We do not include the last round when the children were around 15 years old due to the non-availability of anthropometric measurements. We also exclude observations with missing values and those with abnormal anthropometric outcomes (height-for-age z-score $<-5$ or $>5$ ). The final sample for our empirical analysis consists of 1209 children from rural households for whom we have information for all our variables of interest from 2002 to 2013. We do not consider the 2016 survey as anthropometric information was not available.

Ethical statement: The current study uses data from the Young Lives Surveys which are available publicly at: https://www.younglives.org.uk/content/use-our-data (accessed on 2 October 2019). The Young Lives Surveys obtain ethical clearance from the London School of Hygiene and Tropical Medicine ethics committee (https: / /www.younglives.org. $\mathrm{uk} /$ content/research-ethics) (accessed on 2 October 2019).

\subsection{Dependent Variables}

\subsubsection{Child Nutritional Status}

In this analysis, our main dependent variable child nutritional status is measured using height-for-age z-score (haz). The haz is calculated using children's height/length and date of birth and refers to the number of standard deviations below or above the median height of reference population used by 2006 WHO Children Growth Standard [32]. The reference standards were constructed using the WHO's Multicentre Growth Reference Study conducted between 1997 to 2003 in Brazil, Ghana, India, Norway, Oman, and the USA. The reference standards present possibly normal anthropometric measures of children who were raised in a seemingly optimal environment without any constraints on their linear growth, controlling for socio-economic disparities among them. 
The haz measure shows the extent to which children have either fallen or improved relative to the reference population. A child is defined as being "moderately stunted" if $-3 \leq h a z<-2$ standard deviations below the reference population and as "severely stunted" if $h a z<-3$ standard deviations below the reference population. We therefore use both dependent variables "haz" and "stunting" as dependent variables in our empirical analysis.

\subsubsection{Food Insecurity Status and Dietary Diversity Measures}

The food security measure in the Young Lives survey was based on FAO's Household Food Insecurity Access Scale [33] and focused on the extent to which a household had access to nutritionally adequate food. The food insecurity variables are constructed using self-reported responses to a series of questions on the household's food insecurity status in the last 12 months. These include: (i) Worry about running out of food; (ii) Not able to eat preferred foods; (iii) Eat a limited variety of foods; and (iv) Eat unwanted foods. We create a binary variable for each of these questions, taking on a value of 1 to indicate the household's food insecurity status; 0 otherwise. Respondents were also asked to self-assess their household's food situation in the last 12 months prior to the survey by choosing one of four potential responses. These include: "always eat enough", "eat enough but not always", "sometimes not eat enough", and "frequently not eat enough". We categorize a household as being "food secure" if the respondent chose the first answer, otherwise they are classified as being "food insecure".

In addition, there is detailed data on household consumption of different food items, in the last 15 days prior to the survey, excluding consumption for a festival, feasting, fasting period, wedding, or other unusual events. The respondents were firstly asked to choose all food items that household members consumed in the last 15 days, then provided value of those food items from purchasing, self-producing, and receiving as gifts or transferred. Previous studies from India [27-29] have used slightly different methods to disaggregate overall food expenditure into food groups but have all included five main groups: (1) tubers and cereals, (2) fruits and vegetables, (3) eggs, (4) milk and dairy products, and (5) meat and fish. We combine pulses with fruits and vegetables as pulse expenditure only accounted for nearly $4 \%$ of total food expenditure on average. Therefore, we categorize all the food items into the following five groups: (i) tubers and cereals, (ii) fruits, vegetables, and pulses, (iii) eggs, (iv) milk and dairy products, and (v) meat and fish.

Accordingly, we use three groups of dependent variables: a household's food insecurity status, household's dietary diversity (proportion of each food group in total consumption), and finally as a robustness check we include the purchased value of food among all sources of food for each food group. Information on food security was only collected consistently in 2009 and 2013. Food insecurity status was collected in 2006, but the questionnaire was different compared with 2009 and 2013, while household food consumption was collected in 2006, 2009, and 2013. To make the analysis consistent by using the same sample for all the three groups of dependent variables, we only investigate the household's food insecurity status, dietary diversity, and purchased value of food groups in 2009 and 2013. The dependent variables included in our analysis by years of survey are shown in Table A1 in the Appendix A.

\subsection{Explanatory Variables}

Our main explanatory variables include household's agricultural land-owning status, the occupation of household heads, particularly their participation in farm and non-farm activities.

\subsubsection{Ownership of Agricultural Land}

Detailed information was collected on all types of agricultural land ownership, in particular whether the household owned, borrowed, rented, or sharecropped in the last agriculture year in 2002, 2006, 2009, and 2013. We focus on agricultural land owned by the surveyed households, as ownership of agricultural land allows households to make production-related decisions. Specifically, in keeping with the classification used in the 
Agricultural Census of India we categorize households as being marginal landowners if they own $<1.25$ acres, small landowners if they own $1.25-5$ acres, and large landowners if they own $>5$ acres.

\subsubsection{Household Livelihoods}

In the survey, respondents reported the main occupations of household members over the last 12 months. In our main analysis, a household is categorized as being involved in farm work if a majority of members were self-employed or employed in agriculture as a wage employee, were annual farmer workers, or had other agricultural jobs. Similarly, a household is classified as being involved in non-farm livelihoods if more than half the household members were employed in non-farm activities. A household was classified as having a balanced farm/non-farm livelihood if an equal number of household members were employed in farm and non-farm activities.

We also control for the social context, in particular the caste system. Caste has been empirically shown to be closely associated with inequality in India, in which lower-caste households are more disadvantaged in accessing land and productive assets, and therefore appear to have lower income and poorer access to food [34]. We additionally control for the household's socio-economic, demographic, and geographic characteristics, by including variables such as geographical region, religion, wealth quintiles, characteristics of household head (age, gender, and educational attainment), household size, and the ratio of children aged under five out of the household size. Social programs such as Public Distribution System (PDS), National Rural Employment Generation Scheme (NREGS), Rajiv Aarogyasri Health Insurance Scheme (RAJIV) and Indira Kranthi Patham Project (IKP) may improve access to food and healthcare in India [35]. Unfortunately, information on these programs' participation were missing in 2002 and 2006. In an attempt to control for this, we include a variable indicating if the households participated into any among those programs. The empirical results suggest that the social programs are statistically insignificant and do not affect our main results. Therefore, we decided not to include this variable in our main analysis.

We also include children's age and gender as controls. We include the educational attainment of primary caregivers, noting that in most cases they were typically the child's mother. Access to safe drinking water and clean toilets have been associated with an improvement in sanitation and hygiene that has been found to reduce child undernutrition $[36,37]$. Accordingly, we include variables indicating access to safe drinking water and clean toilets in the analysis.

Finally, there was a severe drought in the surveyed region in 2002 that may adversely affect child nutritional status [30]. The Young Lives Survey collected information on whether the household was affected by droughts, although this information was not available in 2002. We assume that a child was affected by the 2002 drought if that child was not stunted in 2002, but was stunted in 2006.

\subsection{Empirical Strategy}

In the empirical analysis, we use pooled and fixed-effects models for the continuous dependent variable (haz), and Probit models for the discrete dependent variables (stunting, moderate stunting, and severe stunting).

\subsubsection{OLS Estimates}

In the OLS specification, the general model is written as:

$$
\text { haz }_{j}=\alpha_{0}+\alpha_{1} \text { land }_{j}+\alpha_{2} \text { livelihood }_{j}+\alpha_{3} X_{j}+\lambda_{i}+\tau_{t}+\varepsilon
$$

where the subscript ' $j$ ' indicates the $j^{\text {th }}$ child; $l_{a n d}$ indicates category of the household's agricultural land sizes (landless, marginal, small, and large) where children are residing, and livelihood $_{j}$ indicates if the household's livelihood; and $X_{j}$ is a vector of children's, caregivers' and households' characteristics; $\lambda_{r}$ indexes region dummies; $\tau_{t}$ indexes year 
dummies; and $\varepsilon$ is the error term. The coefficient $\alpha_{1}$ and $\alpha_{2}$ capture the influence of land and livelihoods on haz.

\subsubsection{Panel Fixed-Effects}

The naÏve OLS estimates may be biased due to the influence of time-invariant unobserved heterogeneity across individuals. These could include variables such as their genetic characteristics, pre-natal maternal health, birth weight, childhood congenital diseases or physical abnormality. These biases can be minimized by using Panel Fixed- or Random-effects models. The general model is given as:

$$
\text { haz }_{i t}=\beta_{0}+\beta_{1} \text { land }_{i t}+\beta_{2} \text { livelihood }_{i t}+\beta_{3} X_{i t}+\lambda_{i}+\tau_{t}+\omega_{i}+u_{i t}
$$

where the subscript ' $i t$ ' indicates child $i$ in year $t$; the terms land $_{i t}$, livelihood ${ }_{i t}$, and $X_{i t}$ are interpreted as in Model $1 ; \omega_{i}$ represents the unobserved time-invariant characteristics determining child nutritional status that is correlated and uncorrelated with the explanatory variables in Fixed- and Random-effects models, respectively; and $u_{i t}$ is a random error term.

We choose the more appropriate model based on results from a Hausman test of the correlation between $\omega \_i$ and the explanatory variables, with the null hypothesis that there is no significant correlation indicating that the preferred model is the Random-effects model. The results show statistical significance at $p<0.01$ (Table 5), indicating that there is enough evidence to reject the null hypothesis and use a Fixed-effects model.

\subsubsection{Probit Marginal Effects}

For the other binary dependent variables, we employ Random-effects Probit models. The models assume that the heterogeneity between children is random, which allows for us to include time-invariant characteristics such as the child's gender, caste, and religion as explanatory variables in the analysis. We report marginal effects to reflect the influence of each explanatory variable on children's probability of being stunted, moderately stunted, and severely stunted, holding all other explanatory variables constant.

\section{Results and Discussion}

\subsection{Descriptive Statistics}

\subsubsection{Characteristics of the Panel Sample}

The socio-economic and demographic characteristics of our sample are presented in Tables 1-3. Table 1 presents the descriptive statistics in overall (Panel A and for each of the survey years (Panel B). From Table 1, we observe that approximately $34.3 \%$ of the children in our sample are stunted, with severe stunting observed among $7.3 \%$ of the children. We also observe a significant worsening of haz ( -1.33 to -1.75 standard deviations (SDs)), stunting (33\% to 39\%), and moderate stunting (22\% to 32.5\%) between 2002 and 2006 . This likely reflects the adverse effects of the drought of 2002.

Although there were improvements observed in each of the subsequent waves from 2006 to 2013, child nutritional outcomes were still worse off in 2013 compared to 2002. In particular, mean haz reduced from being -1.33 SDs below the reference population in 2002 to -1.56 SDs below the reference population in 2013. The incidence of stunting decreased slightly from $33 \%$ to $31 \%$ and severe stunting reduced from $11 \%$ to approximately $5.7 \%$ in this period. This is in keeping with the findings of Singh et al. [30], who use the same dataset to show that the severe drought that occurred in this region in 2002 impacted negatively on child stunting among young children. They find that, although complementary feeding through midday meal schemes would have mitigated the negative effects of the drought for this cohort, it was not enough to reduce the growth deficits.

From Table 1, we also observe that, while the size of average household land ownership remained around 2.2 acres throughout the period, between 2002 and 2013 there was a shift in livelihoods, away from farm work. In particular, households whose farm was the main work accounted for $76.7 \%$ in 2002 and the proportion reduced to $62.5 \%$ in 2013, and the proportion of households who had a balance in farm and non-farm work rose from $10.3 \%$ to $18.4 \%$ between 
these years (Table 1). Over the study period 2002-2013, there is a notable decrease in land ownership at the upper end ( $>5$ acres), from $13.1 \%$ in 2002 to $8.7 \%$ in 2013 , and at the lower end among landless and marginal farmers (decreasing from $57.5 \%$ to $49.8 \%$ ). On the other hand, there was an increase in small landowners from $29.4 \%$ to $41.5 \%$ in 2013.

Only about $10 \%$ of the children in our survey were from households classified as being large landowners in Andhra Pradesh and Telangana. Approximately $92 \%$ of the households have access to safe water sources, but only $13 \%$ of them use clean toilets. Generally, we observe a slight improvement in hygiene and sanitation between 2002 and 2013.

Table 1. Descriptive Statistics of the Study Variables.

\begin{tabular}{|c|c|c|c|c|}
\hline \multicolumn{5}{|l|}{ Panel A: Means in overall } \\
\hline Height-for-age z score (haz) & \multicolumn{4}{|c|}{-1.558} \\
\hline Stunting & \multicolumn{4}{|c|}{0.343} \\
\hline Moderate stunting & \multicolumn{4}{|c|}{0.269} \\
\hline Severe stunting & \multicolumn{4}{|c|}{0.073} \\
\hline Panel B: Means by year & 2002 & 2006 & 2009 & 2013 \\
\hline Height-for-age z score (haz) & -1.330 & -1.748 & -1.592 & -1.560 \\
\hline Stunting & 0.333 & 0.394 & 0.330 & 0.315 \\
\hline Moderate stunting & 0.223 & 0.325 & 0.271 & 0.258 \\
\hline Severe stunting & 0.109 & 0.069 & 0.059 & 0.057 \\
\hline \multicolumn{5}{|l|}{ Households' ownership of agricultural land } \\
\hline Area of agricultural land owned (acres) & 2.429 & 2.010 & 2.290 & 2.215 \\
\hline Landless households & 0.373 & 0.415 & 0.279 & 0.286 \\
\hline Marginal landowner: Own $<1.25$ acres & 0.202 & 0.193 & 0.227 & 0.212 \\
\hline Small landowner: Own 1.25-5 acres & 0.294 & 0.309 & 0.403 & 0.415 \\
\hline Large landowners: Own > 5 acre & 0.131 & 0.084 & 0.091 & 0.087 \\
\hline \multicolumn{5}{|l|}{ Household livelihoods } \\
\hline Farm is the main work & 0.767 & 0.606 & 0.566 & 0.625 \\
\hline Non-farm is the main work & 0.131 & 0.284 & 0.266 & 0.190 \\
\hline Balance in farm and non-farm work & 0.103 & 0.110 & 0.169 & 0.184 \\
\hline \multicolumn{5}{|l|}{ Child characteristics } \\
\hline Child is female & 0.471 & 0.471 & 0.471 & 0.471 \\
\hline Child's age (years) & 0.985 & 5.357 & 7.938 & 11.967 \\
\hline \multicolumn{5}{|l|}{ Household characteristics } \\
\hline Head's age & 40.240 & 38.954 & 38.571 & 41.220 \\
\hline Head is female & 0.084 & 0.052 & 0.056 & 0.109 \\
\hline Head completed primary education & 0.156 & 0.290 & 0.373 & 0.385 \\
\hline Head completed secondary education or higher & 0.126 & 0.208 & 0.258 & 0.251 \\
\hline Caregiver completed primary education & 0.165 & 0.253 & 0.333 & 0.328 \\
\hline Caregiver completed secondary education or higher & 0.088 & 0.127 & 0.135 & 0.133 \\
\hline Household size & 5.620 & 5.691 & 5.587 & 4.934 \\
\hline Ratio of children aged under five & 0.052 & 0.103 & 0.086 & 0.022 \\
\hline Region: Telangana & 0.330 & 0.332 & 0.331 & 0.335 \\
\hline Region: Coastal & 0.337 & 0.336 & 0.337 & 0.335 \\
\hline Region: Rayalaseema & 0.333 & 0.333 & 0.333 & 0.330 \\
\hline Caste: Scheduled Caste (SC) & 0.203 & 0.203 & 0.203 & 0.203 \\
\hline Caste: Scheduled Tribes (ST) & 0.190 & 0.190 & 0.190 & 0.190 \\
\hline Caste: Other Backward Caste (BC) & 0.472 & 0.472 & 0.472 & 0.472 \\
\hline Religion: Hindu & 0.929 & 0.929 & 0.929 & 0.929 \\
\hline Access to safe water sources & 0.797 & 0.928 & 0.958 & 0.986 \\
\hline Access to clean toilets & 0.099 & 0.113 & 0.135 & 0.189 \\
\hline Wealth quintile: Poorest & 0.367 & 0.246 & 0.132 & 0.060 \\
\hline Wealth quintile: Poorer & 0.258 & 0.239 & 0.189 & 0.108 \\
\hline Wealth quintile: Middle & 0.208 & 0.232 & 0.239 & 0.146 \\
\hline Wealth quintile: Richer & 0.104 & 0.179 & 0.231 & 0.272 \\
\hline Wealth quintile: Richest & 0.062 & 0.103 & 0.209 & 0.413 \\
\hline Observations & 1209 & 1209 & 1209 & 1209 \\
\hline
\end{tabular}




\subsubsection{Child Nutritional Status by Land Size and Livelihoods}

In Table 2, for landholding households we present data on children's haz and stunting incidence disaggregated by household land size. Notably, there are statistically significant differences in child nutrition, particularly in early childhood and in the drought year 2002. In particular, children from landless households have a haz of -1.413 SDs and stunting incidence was $34.8 \%$. On the other hand, children from households owning more than 5 acres of land have significantly better haz (-0.93) and a stunting incidence of $20 \%$. The incidence of severe stunting is also less than a third among children from the largest land holding households (3.8\% compared to $11.5 \%$ among children from landless households).

We do not observe any statistically significant effects in subsequent waves, suggesting that landless households were able to mitigate some of the potential adverse effects of the drought on child nutrition.

Table 2. Child Nutritional Status by Household Landholding Status.

\begin{tabular}{|c|c|c|c|c|}
\hline \multirow[b]{3}{*}{ Child nutritional status } & \multicolumn{4}{|c|}{ Household Agricultural Landowning } \\
\hline & \multicolumn{2}{|c|}{$\begin{array}{l}\text { Group 1: } \\
\text { Landless }\end{array}$} & \multicolumn{2}{|c|}{$\begin{array}{c}\text { Group 2: } \\
\text { Own }>5 \text { Acres of Land }\end{array}$} \\
\hline & Mean & SD & Mean & SD \\
\hline $\begin{array}{c}\text { Panel A: } 2002 \\
\text { Height-for-age }(\text { haz }) \\
\text { Stunting }(\text { haz }<-2) \\
\text { Moderate stunting }(-3<h a z<-2) \\
\text { Severe stunting }(\text { haz }<-2) \\
\text { Observations }\end{array}$ & $\begin{array}{c}-1.413^{* * * *} \\
0.348^{* * *} \\
0.233 \\
0.115^{* * *} \\
451\end{array}$ & $\begin{array}{c}1.442 \\
0.477 \\
0.423 \\
0.32\end{array}$ & $\begin{array}{c}-0.926 \\
0.203 \\
0.165 \\
0.038 \\
158\end{array}$ & $\begin{array}{l}1.406 \\
0.403 \\
0.372 \\
0.192\end{array}$ \\
\hline $\begin{array}{c}\text { Panel B: } 2006 \\
\text { Height-for-age }(h a z) \\
\text { Stunting }(h a z<-2) \\
\text { Moderate stunting }(-3<\text { haz }<-2) \\
\text { Severe stunting }(\text { haz }<-2) \\
\text { Observations }\end{array}$ & $\begin{array}{c}-1.72 \\
0.378 * \\
0.309 \\
0.07 \\
502\end{array}$ & $\begin{array}{l}0.908 \\
0.485 \\
0.462 \\
0.255\end{array}$ & $\begin{array}{c}-1.583 \\
0.277 \\
0.218 \\
0.059 \\
101\end{array}$ & $\begin{array}{c}0.851 \\
0.45 \\
0.415 \\
0.238\end{array}$ \\
\hline $\begin{array}{c}\text { Panel C: } 2009 \\
\text { Height-for-age }(\text { haz }) \\
\text { Stunting }(\text { haz }<-2) \\
\text { Moderate stunting }(-3<\text { haz }<-2) \\
\text { Severe stunting }(\text { haz }<-2) \\
\text { Observations }\end{array}$ & $\begin{array}{c}-1.554 \\
0.32 \\
0.243 \\
0.077 \\
337\end{array}$ & $\begin{array}{c}0.983 \\
0.467 \\
0.43 \\
0.267\end{array}$ & $\begin{array}{c}-1.506 \\
0.3 \\
0.245 \\
0.055 \\
110\end{array}$ & $\begin{array}{c}0.861 \\
0.46 \\
0.432 \\
0.228\end{array}$ \\
\hline $\begin{array}{c}\text { Panel D: } 2013 \\
\text { Height-for-age }(h a z) \\
\text { Stunting }(\text { haz }<-2) \\
\text { Moderate stunting }(-3<\text { haz }<-2) \\
\text { Severe stunting }(\text { haz }<-2) \\
\text { Observations }\end{array}$ & $\begin{array}{c}-1.493 \\
0.298 \\
0.234 \\
0.064 \\
346\end{array}$ & $\begin{array}{l}0.978 \\
0.458 \\
0.424 \\
0.244\end{array}$ & $\begin{array}{c}-1.518 \\
0.305 \\
0.267 \\
0.038 \\
105\end{array}$ & $\begin{array}{l}0.942 \\
0.463 \\
0.444 \\
0.192\end{array}$ \\
\hline
\end{tabular}

Notes: $T$-tests are used for the null hypothesis that there is no difference between Group 1 and Group 2. ${ }^{*} p<0.1,{ }^{* * *} p<0.01$.

In Table 3, we present child nutrition indicators disaggregated by households' farm and non-farm livelihoods. While there is no statistically significant difference between the two groups, we do observe that in early childhood in 2002, the haz is better for households involved in farm compared to non-farm. However, the drought in 2002 may have adversely affected farming households, as child nutrition is better in non-farming households in waves 2006, 2009, and 2013. 
Table 3. Child Nutritional Status by Household Livelihoods.

\begin{tabular}{|c|c|c|c|c|}
\hline \multirow[b]{3}{*}{ Child nutritional status } & \multicolumn{4}{|c|}{ Household Livelihoods } \\
\hline & \multicolumn{2}{|c|}{$\begin{array}{c}\text { Group 1: Farming-Main Source of } \\
\text { Employment }\end{array}$} & \multicolumn{2}{|c|}{$\begin{array}{l}\text { Group 2: Non-Farm-Main } \\
\text { Source of Employment }\end{array}$} \\
\hline & Mean & SD & Mean & SD \\
\hline $\begin{array}{c}\text { Panel A: } 2002 \\
\text { Height-for-age }(h a z) \\
\text { Stunting }(\text { haz }<-2) \\
\text { Moderate stunting }(-3<h a z<-2) \\
\text { Severe stunting }(\text { haz }<-2) \\
\text { Observations }\end{array}$ & $\begin{array}{c}-1.318 \\
0.331 \\
0.227 \\
0.104 \\
1.051\end{array}$ & $\begin{array}{l}1.481 \\
0.471 \\
0.419 \\
0.305\end{array}$ & $\begin{array}{c}-1.413 \\
0.342 \\
0.196 \\
0.146 \\
158\end{array}$ & $\begin{array}{l}1.476 \\
0.476 \\
0.398 \\
0.354\end{array}$ \\
\hline $\begin{array}{c}\text { Panel B: } 2006 \\
\text { Height-for-age }(h a z) \\
\text { Stunting }(\text { haz }<-2) \\
\text { Moderate stunting }(-3<h a z<-2) \\
\text { Severe stunting }(\text { haz }<-2) \\
\text { Observations }\end{array}$ & $\begin{array}{c}-1.774 \\
0.406 \\
0.341 \\
0.066 \\
866\end{array}$ & $\begin{array}{l}0.876 \\
0.491 \\
0.474 \\
0.248\end{array}$ & $\begin{array}{c}-1.685 \\
0.362 \\
0.286 \\
0.076 \\
343\end{array}$ & $\begin{array}{l}0.918 \\
0.481 \\
0.452 \\
0.265\end{array}$ \\
\hline $\begin{array}{c}\text { Panel C: } 2009 \\
\text { Height-for-age }(h a z) \\
\text { Stunting }(\text { haz }<-2) \\
\text { Moderate stunting }(-3<h a z<-2) \\
\text { Severe stunting }(\text { haz }<-2) \\
\text { Observations }\end{array}$ & $\begin{array}{c}-1.621 \\
0.336 \\
0.283 \\
0.053 \\
888\end{array}$ & $\begin{array}{l}0.891 \\
0.472 \\
0.451 \\
0.224\end{array}$ & $\begin{array}{c}-1.512 \\
0.315 \\
0.24 \\
0.075 \\
321\end{array}$ & $\begin{array}{l}1.013 \\
0.465 \\
0.428 \\
0.263\end{array}$ \\
\hline $\begin{array}{c}\text { Panel D: } 2013 \\
\text { Height-for-age }(h a z) \\
\text { Stunting }(\text { haz }<-2) \\
\text { Moderate stunting }(-3<h a z<-2) \\
\text { Severe stunting }(\text { haz }<-2) \\
\text { Observations }\end{array}$ & $\begin{array}{c}-1.595 * \\
0.323 \\
0.266 \\
0.057 \\
979\end{array}$ & $\begin{array}{l}0.919 \\
0.468 \\
0.442 \\
0.232\end{array}$ & $\begin{array}{c}-1.411 \\
0.283 \\
0.226 \\
0.057 \\
230\end{array}$ & $\begin{array}{c}0.99 \\
0.451 \\
0.419 \\
0.231\end{array}$ \\
\hline
\end{tabular}

Notes: $T$-tests are used for the null hypothesis that there is no difference between Group 1 and Group $2 .{ }^{*} p<0.1$.

To better understand the factors driving food and nutrition security among farming households, in Table 4 we focus on the food consumption patterns among the 610 land-owning households. The figures are only available over the period 2009-2013 since information on food consumption was not collected in 2002, and consistently collected in 2006 compared to the two later survey years. Nevertheless, this gives us information on self-reported household food security and dietary diversity among agricultural landholding households. Although household food insecurity has declined significantly, it is still high among households in our sample. On average, approximately $72.2 \%$ of households experienced food insecurity, $26.6 \%$ report being worried about not having enough food, $61.5 \%$ of the households could not eat their preferred food, $30.1 \%$ consumed a limited variety of food, and $21.3 \%$ ate unwanted food.

In terms of dietary composition, the consumption of staples such as tubers, cereals, fruits, vegetables, and pulses still accounted for more than half of total household food consumption, and this proportion remained unchanged between the two periods. Meat and fish made up about $11 \%$, followed by eggs, milk, and dairy products.

In Table 4, we also report the proportion of food consumption that is purchased from markets. Approximately $75.3 \%$ of food consumption within landowning households was purchased from markets, the highest proportion was observed for meat, fish, fruits, vegetables, and pulses. However, with regards to food commodities such as tubers, cereals, milk, and dairy products, our results suggest that in the sample of agricultural landowning households, own-production and livestock ownership still plays a crucial role. Notably, there is only a small increase in the proportion of tubers and cereals purchased (from $47.1 \%$ in 2009 to $49.6 \%$ in 2013), with a small reduction in the consumption of purchased meat and fish, milk and dairy products, and fruits, vegetables, and pulses between 2009 and 2013. 
The decline in consumption of the seemingly more expensive food items in this period may be a consequence of the raising food price crisis in 2008 [11].

Table 4. Food Consumption for a Panel of 610 Agricultural Landowning Households.

\begin{tabular}{|c|c|c|c|}
\hline \multirow[b]{2}{*}{ Variable } & \multicolumn{3}{|c|}{ Means } \\
\hline & Overall & 2009 & 2013 \\
\hline \multicolumn{4}{|l|}{ Food security status in the last 12 months } \\
\hline Experience food insecurity status & 0.722 & 0.759 & 0.685 \\
\hline Worry about food & 0.266 & 0.252 & 0.280 \\
\hline Not eat preferred food & 0.615 & 0.741 & 0.489 \\
\hline Eat a limited variety of food & 0.301 & 0.323 & 0.279 \\
\hline Eat unwanted food & 0.213 & 0.285 & 0.141 \\
\hline \multirow{2}{*}{\multicolumn{4}{|c|}{$\begin{array}{l}\text { Dietary diversity in the last } 2 \text { weeks } \\
\text { (Proportion of each food group in food consumption) }\end{array}$}} \\
\hline & & & \\
\hline Proportion of tubers \& cereals & 0.242 & 0.249 & 0.235 \\
\hline Proportion of fruits, vegetables \& pulses & 0.263 & 0.265 & 0.260 \\
\hline Proportion of eggs & 0.016 & 0.014 & 0.017 \\
\hline Proportion of milk \& dairy products & 0.072 & 0.065 & 0.080 \\
\hline Proportion of meat \& fish & 0.110 & 0.105 & 0.114 \\
\hline Proportion of other food items & 0.242 & 0.249 & 0.235 \\
\hline \multicolumn{4}{|l|}{ Proportion of purchased food in consumption } \\
\hline Proportion of all consumed food items & 0.753 & 0.757 & 0.748 \\
\hline Proportion of consumed tubers \& cereals & 0.483 & 0.471 & 0.496 \\
\hline Proportion of consumed fruits, vegetables \& pulses & 0.835 & 0.837 & 0.834 \\
\hline Proportion of consumed eggs & 0.672 & 0.656 & 0.688 \\
\hline Proportion of consumed milk \& dairy products & 0.537 & 0.541 & 0.533 \\
\hline Proportion of consumed meat \& fish & 0.804 & 0.818 & 0.790 \\
\hline Observations & 1220 & 610 & 610 \\
\hline
\end{tabular}

Notes: The sample includes households who owned agricultural land and were repeatedly surveyed in 2009 and 2013.

\subsection{Empirical Results}

Tables 5 and 6 presents the main empirical results showing OLS, Fixed-effects, and Probit estimation on the associations between child nutrition, household land ownership, and livelihoods. The key findings from our analyses can be summarized as follows: Firstly, children from farming households with $>5$ acres of land have significantly higher haz, and a significantly lower probability of being stunted, relative to children from landless households. Secondly, in the sample of landless households, we observe that a transition from farm to non-farm work is associated with an improvement in haz between 2006 and 2013. Thirdly, our robustness results show that among landholding households, agriculture production diversity is associated with a greater dietary diversity of consumption (more consumption of fruits, vegetables, and pulses). Finally, we observe a statistically significant and large effects of the drought of 2002 on child stunting.

OLS and Fixed-effects models are presented for haz in Table 5 (Columns 1 and 2) and Probit model estimates are presented for the probability of being stunted, moderately stunted, and severely stunted in Table 6 (Columns 1-3). 
Table 5. Regression Estimates: The Effect of Household Land and Livelihoods on Children's Haz.

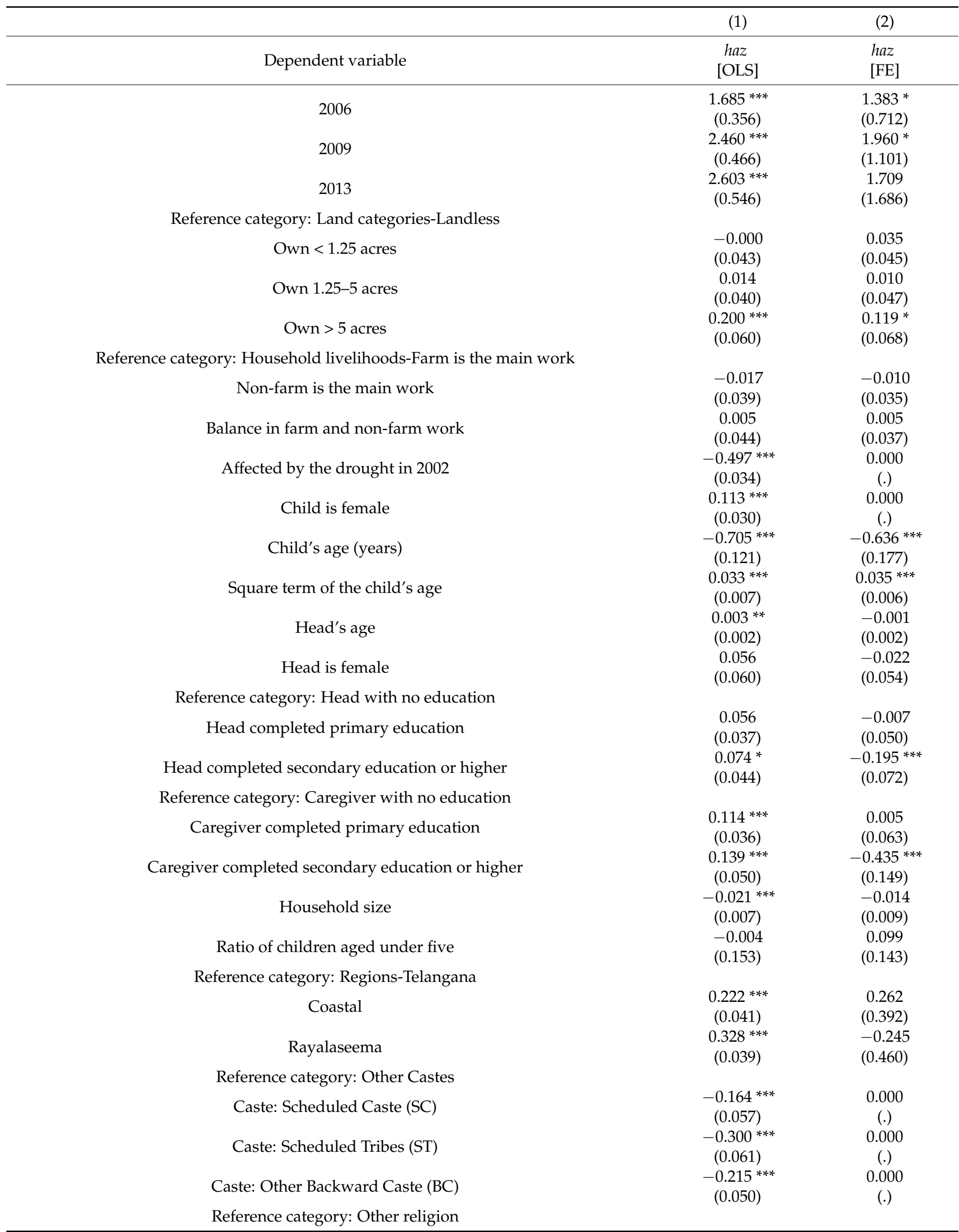


Table 5. Cont.

\begin{tabular}{|c|c|c|}
\hline & (1) & (2) \\
\hline Dependent variable & $\begin{array}{c}\text { haz } \\
\text { [OLS] }\end{array}$ & $\begin{array}{l}\text { haz } \\
{[\mathrm{FE}]}\end{array}$ \\
\hline Religion: Hindu & $\begin{array}{l}-0.003 \\
(0.065)\end{array}$ & $\begin{array}{c}0.000 \\
(.)\end{array}$ \\
\hline Access to safe water sources & $\begin{array}{l}0.129 * * \\
(0.064)\end{array}$ & $\begin{array}{c}0.197^{* * *} \\
(0.057)\end{array}$ \\
\hline Access to clean toilets & $\begin{array}{c}0.145^{* * *} \\
(0.054)\end{array}$ & $\begin{array}{c}0.045 \\
(0.049)\end{array}$ \\
\hline \multicolumn{3}{|l|}{ Reference category: Poorest quintile } \\
\hline Wealth quintile: Poorer & $\begin{array}{c}0.174^{* * *} \\
(0.053)\end{array}$ & $\begin{array}{c}0.063 \\
(0.049)\end{array}$ \\
\hline Wealth quintile: Middle & $\begin{array}{c}0.162 * * * \\
(0.053)\end{array}$ & $\begin{array}{l}0.089^{*} \\
(0.050)\end{array}$ \\
\hline Wealth quintile: Richer & $\begin{array}{c}0.278^{* * *} \\
(0.053)\end{array}$ & $\begin{array}{l}0.124^{* *} \\
(0.055)\end{array}$ \\
\hline Wealth quintile: Richest & $\begin{array}{c}0.278^{* * *} \\
(0.061)\end{array}$ & $\begin{array}{l}0.153^{* *} \\
(0.064)\end{array}$ \\
\hline Constant & $\begin{array}{c}-0.967^{* * *} \\
(0.168)\end{array}$ & $\begin{array}{c}-0.819^{* * *} \\
(0.291)\end{array}$ \\
\hline$p$-value (Hausman test) & & 0.000 \\
\hline Observations & 4836 & 4836 \\
\hline
\end{tabular}

Notes: FE stands for Fixed-effects. We choose FE models when null hypothesis: preferred model, i.e., the Random-effects is rejected. OLS regression and FE models reports the coefficients; Robust standard errors in parentheses (we do not cluster standard errors since a small number of children changed their residential places in the survey years). ${ }^{*} p<0.1,{ }^{* *} p<0.05,{ }^{* * *} p<0.01$.

Table 6. Regression Estimates: The Effect of Household Land and Livelihoods on Child Stunting.

Dependent variable

2006

2009

2013

Reference category: Land categories-Landless

$$
\text { Own }<1.25 \text { acres }
$$

Own $1.25-5$ acres

Own $>5$ acres

Reference category: Household livelihoods-Farm is the main work

Non-farm is the main work

Balance in farm and non-farm work

Affected by the drought in 2002

Child is female

Child's age (years)

Square term of the child's age
(1)

Stunted

(2)

(3)

\begin{tabular}{|c|c|c|}
\hline $\begin{array}{c}\text { Stunted } \\
(\text { haz }<-2) \\
{[\text { Probit] }}\end{array}$ & $\begin{array}{c}\text { Severely Stunted } \\
\text { [Probit] }\end{array}$ & $\begin{array}{c}\text { Moderately Stunted } \\
\text { [Probit] }\end{array}$ \\
\hline $\begin{array}{l}-2.587 \text { *** } \\
(0.753)\end{array}$ & $\begin{array}{l}-1.122 * \\
(0.636)\end{array}$ & $\begin{array}{c}-3.340^{* * *} \\
(0.983)\end{array}$ \\
\hline$-3.877^{* * *}$ & $-2.048^{* *}$ & $-3.973^{* * *}$ \\
\hline (1.121) & $(0.923)$ & $(1.476)$ \\
\hline$-4.437^{* * *}$ & $-2.884^{* *}$ & -3.048 \\
\hline$(1.685)$ & (1.358) & (2.298) \\
\hline 0.048 & 0.067 & 0.007 \\
\hline (0.093) & $(0.081)$ & $(0.130)$ \\
\hline 0.010 & 0.006 & 0.001 \\
\hline$(0.090)$ & $(0.080)$ & (0.129) \\
\hline$-0.262 *$ & -0.146 & -0.358 \\
\hline$(0.150)$ & $(0.132)$ & $(0.225)$ \\
\hline 0.013 & -0.086 & 0.190 \\
\hline$(0.087)$ & $(0.077)$ & (0.122) \\
\hline-0.006 & 0.027 & -0.121 \\
\hline (0.091) & $(0.084)$ & (0.134) \\
\hline $1.227^{* * *}$ & $1.138^{* * *}$ & -0.030 \\
\hline$(0.090)$ & $(0.076)$ & (0.173) \\
\hline$-0.214^{* *}$ & $-0.165^{* *}$ & 0.026 \\
\hline$(0.105)$ & $(0.078)$ & (0.128) \\
\hline $0.925^{* * *}$ & $0.450 * *$ & $1.057^{* * *}$ \\
\hline$(0.216)$ & $(0.190)$ & $(0.288)$ \\
\hline$-0.039 * * *$ & -0.012 & $-0.062^{* * *}$ \\
\hline$(0.012)$ & $(0.011)$ & $(0.018)$ \\
\hline
\end{tabular}


Table 6. Cont.

\begin{tabular}{|c|c|c|c|}
\hline & $(1)$ & $(2)$ & (3) \\
\hline Dependent variable & $\begin{array}{c}\text { Stunted } \\
(\text { haz }<-2) \\
{[\text { Probit }]}\end{array}$ & $\begin{array}{l}\text { Severely Stunted } \\
\text { [Probit] }\end{array}$ & $\begin{array}{c}\text { Moderately Stunted } \\
\text { [Probit] }\end{array}$ \\
\hline Head's age & $\begin{array}{l}-0.003 \\
(0.003)\end{array}$ & $\begin{array}{l}-0.000 \\
(0.003)\end{array}$ & $\begin{array}{l}-0.010 * \\
(0.005)\end{array}$ \\
\hline Head is female & $\begin{array}{l}-0.014 \\
(0.123)\end{array}$ & $\begin{array}{l}-0.050 \\
(0.110)\end{array}$ & $\begin{array}{c}0.009 \\
(0.189)\end{array}$ \\
\hline \multicolumn{4}{|l|}{ Reference category: Head with no education } \\
\hline Head completed primary education & $\begin{array}{l}-0.024 \\
(0.094)\end{array}$ & $\begin{array}{l}-0.069 \\
(0.079)\end{array}$ & $\begin{array}{c}0.093 \\
(0.138)\end{array}$ \\
\hline Head completed secondary education or higher & $\begin{array}{l}-0.007 \\
(0.127)\end{array}$ & $\begin{array}{l}-0.005 \\
(0.104)\end{array}$ & $\begin{array}{l}-0.196 \\
(0.184)\end{array}$ \\
\hline \multicolumn{4}{|l|}{ Reference category: Caregiver with no education } \\
\hline Caregiver completed primary education & $\begin{array}{l}-0.151 \\
(0.102)\end{array}$ & $\begin{array}{l}-0.116 \\
(0.084)\end{array}$ & $\begin{array}{l}-0.181 \\
(0.142)\end{array}$ \\
\hline Caregiver completed secondary education or higher & $\begin{array}{l}-0.196 \\
(0.167)\end{array}$ & $\begin{array}{l}-0.201 \\
(0.131)\end{array}$ & $\begin{array}{c}0.034 \\
(0.216)\end{array}$ \\
\hline Household size & $\begin{array}{c}0.027 \\
(0.018)\end{array}$ & $\begin{array}{c}0.012 \\
(0.015)\end{array}$ & $\begin{array}{c}0.029 \\
(0.028)\end{array}$ \\
\hline Ratio of children aged under five & $\begin{array}{c}0.263 \\
(0.296)\end{array}$ & $\begin{array}{c}0.188 \\
(0.271)\end{array}$ & $\begin{array}{c}0.121 \\
(0.410)\end{array}$ \\
\hline \multicolumn{4}{|l|}{ Reference category: Regions-Telangana } \\
\hline Coastal & $\begin{array}{l}-0.299 * * \\
(0.136)\end{array}$ & $\begin{array}{l}-0.135 \\
(0.103)\end{array}$ & $\begin{array}{l}-0.338^{* *} \\
(0.162)\end{array}$ \\
\hline Rayalaseema & $\begin{array}{l}-0.569^{* * *} \\
(0.135)\end{array}$ & $\begin{aligned}-0.343^{* * *} & (0.101)\end{aligned}$ & $\begin{aligned}-0.473^{* * *} \\
(0.171)\end{aligned}$ \\
\hline \multicolumn{4}{|l|}{ Reference category: Other Castes } \\
\hline Caste: Scheduled Caste (SC) & $\begin{array}{l}0.432 * * \\
(0.202)\end{array}$ & $\begin{array}{l}0.312 * * \\
(0.154)\end{array}$ & $\begin{array}{c}0.129 \\
(0.246)\end{array}$ \\
\hline Caste: Scheduled Tribes (ST) & $\begin{array}{l}0.671^{* * *} \\
(0.209)\end{array}$ & $\begin{array}{l}0.474^{* * *} \\
(0.158)\end{array}$ & $\begin{array}{c}0.211 \\
(0.254)\end{array}$ \\
\hline Caste: Other Backward Caste (BC) & $\begin{array}{l}0.416^{* *} \\
(0.177)\end{array}$ & $\begin{array}{l}0.312 * * \\
(0.133)\end{array}$ & $\begin{array}{c}0.117 \\
(0.229)\end{array}$ \\
\hline \multicolumn{4}{|l|}{ Reference category: Other religion } \\
\hline Religion: Hindu & $\begin{array}{l}-0.212 \\
(0.211)\end{array}$ & $\begin{array}{l}-0.246 \\
(0.157)\end{array}$ & $\begin{array}{c}0.106 \\
(0.246)\end{array}$ \\
\hline Access to safe water sources & $\begin{array}{l}-0.281^{* *} \\
(0.125)\end{array}$ & $\begin{array}{l}-0.246^{* *} \\
(0.115)\end{array}$ & $\begin{array}{c}0.014 \\
(0.155)\end{array}$ \\
\hline Access to clean toilets & $\begin{array}{c}0.032 \\
(0.107)\end{array}$ & $\begin{array}{l}-0.013 \\
(0.095)\end{array}$ & $\begin{array}{l}-0.005 \\
(0.188)\end{array}$ \\
\hline \multicolumn{4}{|l|}{ Reference category: Poorest quintile } \\
\hline Wealth quintile: Poorer & $\begin{array}{l}-0.125 \\
(0.099)\end{array}$ & $\begin{array}{l}-0.101 \\
(0.088)\end{array}$ & $\begin{array}{l}-0.065 \\
(0.125)\end{array}$ \\
\hline Wealth quintile: Middle & $\begin{array}{l}-0.188^{*} \\
(0.101)\end{array}$ & $\begin{array}{l}-0.077 \\
(0.090)\end{array}$ & $\begin{array}{l}-0.220 \\
(0.140)\end{array}$ \\
\hline Wealth quintile: Richer & $\begin{array}{l}-0.419 * * * \\
(0.114)\end{array}$ & $\begin{array}{l}-0.274^{* * *} \\
(0.101)\end{array}$ & $\begin{array}{l}-0.279 * \\
(0.157)\end{array}$ \\
\hline Wealth quintile: Richest & $\begin{array}{l}-0.391^{* * *} \\
(0.132)\end{array}$ & $\begin{array}{l}-0.134 \\
(0.119)\end{array}$ & $\begin{aligned}- & 0.737^{* * * *} \\
& (0.202)\end{aligned}$ \\
\hline Observations & 4836 & 4836 & 4836 \\
\hline
\end{tabular}

Notes: Probit model reports the marginal effects. Robust standard errors in parentheses (we do not cluster standard errors since a small number of children changed their residential places in the survey years). ${ }^{*} p<0.1,{ }^{* *} p<0.05,{ }^{* * *} p<0.01$.

\subsubsection{Children's Height-for-Age z-Score}

From Table 5, we observe that children from households with $>5$ acres of agricultural land have better nutritional outcomes, relative to landless households or those that own very small parcels of land ( $<1.25$ acres). In particular, children from large-landowning 
households involved have 0.20 SDs higher haz (in OLS estimate in Column 1) and 0.12 SDs higher haz (in the Fixed-effects model in Column 2), relative to the reference category.

Not surprisingly, the drought has a significant negative effect on haz. The children from the households affected by the drought have 0.49 SDs lower haz compared to those not affected by it.

We also observe that relative to 2002, there is a statistically significant and monotonic increase in haz in each of survey rounds. The educational level of the household head and caregiver is positively associated with children's haz in the OLS estimates (Column 1), but the relationships turn negative in the Fixed-effects model (Column 2).

\subsubsection{Child Stunting Probability}

Table 6 shows that relative to a child from a land-owning household, a child from large-landowning households has 26 percentage points lower probability of being stunted. The drought in 2002 has increased the probability of a child being stunted by 123 percentage points, and the probability of being severely stunted by 114 percentage points. The finding that female children have a lower probability of being stunted is unexpected but in keeping with findings of insignificant gender inequality in India [38]. The influence of age effects is as expected: child age is negatively associated with their nutritional status, but the associations turn positive when the children grow older.

As expected, sanitation and hygiene are negatively associated with stunting, confirming previous findings $[36,37,39]$. Finally, social status and household wealth have significant impacts on child nutrition. Children living in upper caste and wealthy households have a significantly higher haz and are less likely to be stunted. For example, relative to a child from the poorest wealth quintile, a child from the richest wealth quintile has 39 and 73 percentage points lower probability of being stunted and severely stunted, respectively (Columns 1 and 3). Meanwhile, a child from Scheduled Tribes and Other Backward Castes has 67 and 42 percentage points lower probability of being stunted compared to a child from other upper castes (Column 1).

The findings on the relationship between household land, livelihoods, and child nutritional status in Tables 5 and 6 are consistent with the descriptive statistics presented in Table 2, and in keeping with previous research from India that greater access to land improves food and nutrition security within farming households [3,12]. However, these studies find that the area of agricultural land owned by a rural household must be large enough for food production and for a household to be food secure. For instance, Pritchard et al. [11] find that rural Indian households with $<4$ hectares are unable to produce a sufficient amount of food for their consumption. The reason may be that marginal and small farming households are easily influenced by market and government failures, and may find it difficult to access agricultural inputs and extension services [40]. They mainly produce low-value products such as rice and wheat, while those owning large parcels of agricultural land have a higher ability to produce high-value products and commercialize production $[30,38]$.

Our results are in line with the findings in Uttarakhand State by Rais et al. [12], who show that for small farming households only have half of the food consumption comes from their own-production. However, households who have access to large parcels of agricultural land may be able to better improve dietary diversity and nutrition through agricultural production rather than through non-farm activities, because in India non-farm employment in the informal sector is mainly casual or being self-employed with low and unstable payment [14]. This could be a reason why non-farm livelihoods showed a negative and insignificant association with the haz in the study population.

The findings also indicate that after a worsening of haz between 2002 and 2006, there was an improvement in child nutrition, specifically child stunting and haz. This is consistent with Singh et al. [30], who found that the 2002 drought in this region negatively impacted on child linear growth. However, there was a subsequent improvement in nutritional outcomes among school-age children, possibly due to the midday meal scheme 
which provided food supplements that enabled some catch-up in child haz. The statistical significance of the year dummy variables does support this claim, and likely accounts for unobserved variable bias and its change over the time.

\subsubsection{The Effect of Transition in Household Livelihoods on Child Nutrition}

Table 7 presents the influence on child nutrition from transition in household livelihoods between farming and non-farm work. Traditionally, lack of land is a major reason for households to shift from farm work to non-farm work with a structural transition in the economy [41,42]. We present the results of the transition in livelihoods separately for land-owning and landless households. We do not observe any statistically significant effects among landowning households. However, among landless households a transition from farm to non-farm is statistically significant and positively associated with an improvement in haz. In particular, the haz is 15 percentage points higher among children whose households shifted from farm to non-farm work, relative to those landless households who did not have any change in livelihood. The findings are in line with previous studies that transition from predominately farm to non-farm as a major livelihood option is greater among landless households compared to land-owning households [43].

Table 7. Probit Marginal Effects: The Influence of Transition in Household Livelihoods on Child Nutrition Status.

\begin{tabular}{|c|c|c|}
\hline \multirow[b]{2}{*}{ Variables } & \multicolumn{2}{|c|}{$\begin{array}{l}\text { Dependent Variables: haz Improved } \\
\text { between 2006-2013 }\end{array}$} \\
\hline & $\begin{array}{c}\text { (1) } \\
\text { Sample of Landowning Households }\end{array}$ & $\begin{array}{c}\text { (2) } \\
\text { Sample of Landless Households }\end{array}$ \\
\hline \multicolumn{3}{|l|}{$\begin{array}{l}\text { Reference category: Transition in } \\
\text { livelihoods-No change }\end{array}$} \\
\hline Farm work to non-farm work & $\begin{array}{l}-0.018 \\
(0.052)\end{array}$ & $\begin{array}{l}0.147 * * \\
(0.061)\end{array}$ \\
\hline Non-farm work to farm work & $\begin{array}{c}0.013 \\
(0.050)\end{array}$ & $\begin{array}{c}0.079 \\
(0.052)\end{array}$ \\
\hline Observations & 707 & 502 \\
\hline
\end{tabular}

Notes: Controls are included for 2006 land size, individual, and household characteristics. Probit model reports the marginal effects. Robust standard errors in parentheses. ${ }^{* *} p<0.05$.

\subsection{Robustness Tests}

We test the robustness of our results by focusing on the 610 landowning households who owned agricultural land and were surveyed in both 2009 and 2013. We use Fixed- and Random-effects models for continuous dependent variables measuring the proportion of each food group consumed (dietary diversity) and the proportion of the purchased value of each food group. Probit models are used for discrete dependent variables measuring household's food insecurity status. Results from the robustness tests are presented in the Appendix A (Tables A1, A2 and A3).

\subsubsection{Food Insecurity Status within Agricultural Landowning Households}

The importance of agricultural land size in improving food and nutrition security is confirmed by the empirical results presented in Table A1. A household owning $>5$ acres has 58,39, and 64 percentage points lower probability of experiencing food insecurity, not being able to eat preferred food, and eating unwanted food, respectively. Besides this, we observe little evidence of the influence of field crops and raising livestock on reducing food insecurity status. One possible reason is that the dependent variables were based on recall over a long period (12 months) and may not accurately reflect food consumption within surveyed households. 


\subsubsection{Dietary Diversity within Agricultural Landowning Households}

To better understand food and nutrition security within landowning households, we analyze the dietary diversity of their food consumption in the 2 weeks prior to the survey (Table A2). We choose Random-effects models based on the results of the Hausman test for each regression (shown in Table A2), and control for the proportion of purchased food within each food group. We observe strong evidence of the influence of field crop production and livestock ownership on the consumption of fruits, vegetables, pulses, milk, and dairy products. These results are in line with the findings of Kumar et al. [43] that agricultural production diversity increased the consumption of fruits, vegetables, and pulses, and is also consistent with the findings of Pritchard et al. [12] that owning land and raising livestock improves household's milk consumption within rural households. On the other hand, the diversity of agricultural production is not significantly associated with the consumption of meat, fish, and eggs. The reason may be that these food items are mainly purchased from markets (Table 4). This finding is further confirmed by the positive associations between consumption of meat, fish and eggs, and the proportion of purchased component of these food items. Notably the coefficient is particularly large for meat and fish (Table A2).

Given the observed importance of purchased food to the consumption of some food groups, we further examine the influence of agricultural production on the proportion of purchased food in Table A3. We choose Fixed- or Random-effects models based on the results of the Hausman test for each regression (shown in Table A3). As expected, owning livestock reduces the proportion of milk and dairy products purchased by 15.8 percentage points. Similarly, an increase of one crop produced by a household decreases the proportion of purchased tubers and cereals by 4 percentage points, and the proportion of purchased fruits, vegetables, and pulses by 3.4 percentage points. The results may explain why child nutritional status worsened in the period between 2002 and 2006, as shown in Table 1. In particular, this may be due to a significant reduction in the proportion of households whose farm work was their major source of livelihood (from $76.7 \%$ in 2002 to $60.6 \%$ in 2006). Unfortunately, we are unable to address the issue of changes in the number of crops and livestock from 2002 to 2006, since detailed information on crop production was not collected in 2002.

\subsubsection{Child Nutritional Status and Migration}

In India, previous research has found an increase in rural-urban migration [11,44], with remittance from migrants empirically improving the investment and purchasing power of their households, and increasing household's dietary diversity [27]. Deshingkar and Start [45] find that migration in Andhra Pradesh is determined by the households access to land, livestock ownership, caste, and household size that are already controlled in our analysis.

Unfortunately, our survey did not collect direct information on migration. However, we have attempted to control for migrant household members by using the information on all types of remittances received, and on changes in residence among children compared to the previous survey round. First, we include a binary variable indicating whether households received any remittance in the last 12 months. This variable is expected to have a positive relationship with child nutritional status because remittances supplement household income. Secondly, the nutritional status of children may be influenced by whether they change their residential location. A child may move if their parents migrate. We control for this by excluding 149 children who changed their residence between 2002-2013. The results presented in Table A4 are consistent with our main analysis in Table 5. A child from households owning $>5$ acres and has a higher haz and a lower probability of being stunted, compared to those from landless households (Panels A and B). We do not observe any statistically significant relationship between receiving remittances and child nutritional status. Furthermore, the size of the coefficients and marginal effects of owning $>5$ acres are 
larger in Panel B compared to those in Panel A. This indicates what we are able to partly control for migration and our results are robust.

\subsubsection{Attrition Bias}

Finally, our main results may be biased due to attrition when we construct panel data of children for analysis. In particular, children who were not repeatedly surveyed may be less healthy and may have died between survey rounds, and these children may be more likely to have a lower haz and higher probability of being stunted. Hence, we conduct a robustness test using pooled data of all eligible children for whom we have anthropometric information (haz $>-5 \mathrm{SDs}$ and $<5 \mathrm{SDs}$ ). Table $\mathrm{A} 5$ shows that the results are consistent for a pooled sample of 5622 observations compared to using the panel data of 4836 observations.

\section{Conclusions}

This paper investigated the associations between ownership of agricultural land, household livelihoods, food security, and child nutrition in rural India, using a unique panel dataset covering a period of eleven years. Our empirical evidence conclusively shows that having a large parcel of agricultural land is strongly associated with better child nutrition outcomes and household food security. In particular, children from households owning $>5$ acres of agricultural land have higher haz and a lower probability of being stunted, compared to those from households owning no agricultural land. The associations between agricultural production, food, and nutrition security were further analyzed in the sub-group of landowning households. Our results show that an increase in the number of field crops and livestock reduces the proportion of food purchased for consumption, a finding that is consistently observed for all main food groups. Migration and sample attrition between surveys do not impact on the relationship between land-livelihoods and child nutritional status.

Our findings also suggest that transition from farm to non-farm work improve child nutritional status, but only among landless households. While access to land is still critical for improving household food and nutrition security among our rural households, there has been a trend towards greater non-farm livelihoods, and a decline in reliance on farming, in particularly among landless and marginal farmers.

From a policy perspective, our findings highlight the stalling or worsening progress in child nutrition indicators observed in the latest NFHS survey, despite the Government of India running several social safety programs. The evidence from Andhra Pradesh and Telangana validates the important role of access to agricultural land in addressing food and nutrition security in rural India.

Author Contributions: Conceptualization, L.V., A.R. and S.G.; methodology, L.V., A.R. and S.G.; software, L.V.; validation, A.R., S.G.; formal analysis, L.V.; investigation, L.V.; resources, L.V.; data curation, L.V.; writing—original draft preparation, L.V.; writing—review and editing, A.R. and S.G.; visualization, L.V.; supervision, A.R. and S.G. All authors have read and agreed to the published version of the manuscript.

Funding: Loan Vu's PhD research was supported by an Australian Government Research Training Program (RTP) Scholarship.

Institutional Review Board Statement: We used a publicly accessible secondary dataset from Young Lives project of the University of Oxford. The details on ethical approval and institutional review board can be accessed at: https:/ / www.younglives.org.uk/sites/www.younglives.org.uk/files/YLWP53-Morrow-EthicsOfResearchWithChildren.pdf (accessed on 2 October 2019).

Informed Consent Statement: We used a publicly accessible secondary dataset from Young Lives project of the University of Oxford. The details on informed consent statement can be accessed at: https:/ /www. younglives.org.uk/sites/www.younglives.org.uk/files/YL-WP53-Morrow-EthicsOfResearchWithChildren. pdf (accessed on 2 October 2019).

Data Availability Statement: Data can be downloaded after free registration on site https: / /www. younglives.org.uk/content/use-our-data (accessed on 2 October 2019). 
Conflicts of Interest: The authors have declared that no competing interests exist.

\section{Appendix A}

Table A1. Probit Model Estimates: Land and Livelihoods Association with Food Security Status among Landowning Households.

\begin{tabular}{|c|c|c|c|c|c|}
\hline & (1) & (2) & (3) & (4) & (5) \\
\hline $\begin{array}{l}\text { Dependent variable: Household's food } \\
\text { insecurity status in the last } 12 \text { months }\end{array}$ & $\begin{array}{l}\text { Experience } \\
\text { food } \\
\text { insecurity }\end{array}$ & $\begin{array}{l}\text { Worry about } \\
\text { food }\end{array}$ & $\begin{array}{l}\text { Not eat } \\
\text { preferred } \\
\text { food }\end{array}$ & $\begin{array}{l}\text { Eat a limited } \\
\text { variety of } \\
\text { food }\end{array}$ & $\begin{array}{c}\text { Eat } \\
\text { unwanted } \\
\text { food }\end{array}$ \\
\hline \multicolumn{6}{|l|}{ Reference category: Own $<1.25$ acres } \\
\hline Own $1.25-5$ acres & $\begin{array}{c}-0.189 * \\
(0.107)\end{array}$ & $\begin{array}{c}-0.369 * * * \\
(0.100)\end{array}$ & $\begin{array}{r}-0.004 \\
(0.098)\end{array}$ & $\begin{array}{l}-0.091 \\
(0.110)\end{array}$ & $\begin{array}{c}-0.266^{* *} \\
(0.110)\end{array}$ \\
\hline Own $>5$ acres & $\begin{array}{l}-0.580 * * * \\
(0.150)\end{array}$ & $\begin{array}{c}-0.386^{* *} \\
(0.162)\end{array}$ & $\begin{array}{l}-0.386^{* * *} \\
(0.146)\end{array}$ & $\begin{array}{l}-0.353^{* *} \\
(0.162)\end{array}$ & $\begin{aligned}- & 0.636^{* * *} \\
& (0.183)\end{aligned}$ \\
\hline $\begin{array}{l}\text { Number of crops produced in the last } 12 \\
\text { months }\end{array}$ & $\begin{array}{r}-0.039 \\
(0.045)\end{array}$ & $\begin{array}{l}-0.067 \\
(0.049)\end{array}$ & $\begin{array}{r}-0.024 \\
(0.046)\end{array}$ & $\begin{array}{l}0.009 \\
(0.047)\end{array}$ & $\begin{array}{r}-0.043 \\
(0.052)\end{array}$ \\
\hline Owning livestock in the last 12 months & $\begin{array}{r}-0.016 \\
(0.098)\end{array}$ & $\begin{array}{l}0.059 \\
(0.101)\end{array}$ & $\begin{array}{r}-0.004 \\
(0.092)\end{array}$ & $\begin{array}{r}-0.072 \\
(0.099)\end{array}$ & $\begin{array}{c}-0.184 * \\
(0.101)\end{array}$ \\
\hline $\begin{array}{l}\text { Have at least } 1 \text { member aged } 15-64 \text { involved in } \\
\text { non-farm work }\end{array}$ & $\begin{array}{r}-0.075 \\
(0.094)\end{array}$ & $\begin{array}{r}-0.020 \\
(0.094)\end{array}$ & $\begin{array}{r}-0.069 \\
(0.089)\end{array}$ & $\begin{array}{c}-0.276^{* * *} \\
(0.101)\end{array}$ & $\begin{array}{r}-0.160 \\
(0.098)\end{array}$ \\
\hline Year dummy & Yes & Yes & Yes & Yes & Yes \\
\hline Household characteristics & Yes & Yes & Yes & Yes & Yes \\
\hline Observations & 1220 & 1220 & 1220 & 1220 & 1220 \\
\hline
\end{tabular}

Notes: Probit models report marginal effects. Robust standard errors in parentheses. ${ }^{*} p<0.1,{ }^{* *} p<0.05,{ }^{* * *} p<0.01$.

Table A2. Random Effects of Land and Livelihoods on the Diversity of Food Consumption of Landowning Households.

\begin{tabular}{|c|c|c|c|c|c|}
\hline & \multicolumn{5}{|c|}{ Dependent Variable: Proportion of Food in Total Consumption } \\
\hline & (1) & (2) & (3) & (4) & (6) \\
\hline Variables & $\begin{array}{c}\text { Tubers \& cereals } \\
\text { [RE] }\end{array}$ & $\begin{array}{c}\text { Fruits, vegetables } \\
\text { \& pulses } \\
{[\mathrm{RE}]}\end{array}$ & $\begin{array}{l}\text { Milk \& dairy } \\
\text { products } \\
\text { [RE] }\end{array}$ & $\begin{array}{c}\text { Meat \& fish } \\
\text { [RE] }\end{array}$ & $\begin{array}{l}\text { Eggs } \\
{[\mathrm{RE}]}\end{array}$ \\
\hline \multicolumn{6}{|l|}{ Reference category: Own $<1.25$ acres } \\
\hline Own $1.25-5$ acres & $\begin{array}{r}-0.012 \\
(0.010)\end{array}$ & $\begin{array}{c}0.012 \\
(0.008)\end{array}$ & $\begin{array}{c}0.002 \\
(0.005)\end{array}$ & $\begin{array}{l}-0.000 \\
(0.005)\end{array}$ & $\begin{array}{l}-0.000 \\
(0.001)\end{array}$ \\
\hline Own $>5$ acres & $\begin{array}{r}-0.016 \\
(0.014)\end{array}$ & $\begin{array}{l}0.019 * \\
(0.010)\end{array}$ & $\begin{array}{c}0.004 \\
(0.008)\end{array}$ & $\begin{array}{r}-0.000 \\
(0.007)\end{array}$ & $\begin{array}{r}-0.001 \\
(0.001)\end{array}$ \\
\hline Number of crops produced in the last 12 months & $\begin{array}{r}-0.001 \\
(0.004)\end{array}$ & $\begin{array}{c}0.009 * * * \\
(0.003)\end{array}$ & $\begin{array}{c}0.001 \\
(0.003)\end{array}$ & $\begin{array}{c}0.000 \\
(0.002)\end{array}$ & $\begin{array}{l}-0.000 \\
(0.000)\end{array}$ \\
\hline Owning livestock in the last 12 months & $\begin{array}{c}0.010 \\
(0.009)\end{array}$ & $\begin{array}{c}-0.026 * * * \\
(0.007)\end{array}$ & $\begin{array}{c}0.017^{* * *} \\
(0.004)\end{array}$ & $\begin{array}{c}0.002 \\
(0.004)\end{array}$ & $\begin{array}{c}0.001 \\
(0.001)\end{array}$ \\
\hline $\begin{array}{l}\text { Have at least } 1 \text { member aged 15-64 involved in } \\
\text { non-farm work }\end{array}$ & $\begin{array}{r}-0.010 \\
(0.009)\end{array}$ & $\begin{array}{r}-0.006 \\
(0.006)\end{array}$ & $0.002(0.004)$ & $\begin{array}{r}-0.003 \\
(0.004)\end{array}$ & $\begin{array}{c}0.001 \\
(0.001)\end{array}$ \\
\hline Proportion of tubers \& cereals from purchase & $\begin{array}{c}0.023 * * \\
(0.010)\end{array}$ & & & & \\
\hline $\begin{array}{l}\text { Proportion of fruits, vegetables, and pulses from } \\
\text { purchase }\end{array}$ & & $\begin{array}{l}-0.053 * * \\
(0.021)\end{array}$ & & & \\
\hline Proportion of milk and dairy products purchased & & & $\begin{array}{c}0.010^{* *} \\
(0.004)\end{array}$ & & \\
\hline Proportion of meat and fish from purchase & & & & $\begin{array}{c}0.114^{* * *} \\
(0.004)\end{array}$ & \\
\hline Proportion of eggs from purchase & & & & & $\begin{array}{l}0.021 * * * \\
(0.001)\end{array}$ \\
\hline Year dummy & Yes & Yes & Yes & Yes & Yes \\
\hline Household characteristics & Yes & Yes & Yes & Yes & Yes \\
\hline Hausman test: $p$-value & 0.149 & 0.113 & 0.306 & 0.227 & 0.588 \\
\hline Observations & 1220 & 1220 & 1220 & 1220 & 1220 \\
\hline
\end{tabular}

Notes: RE stands for Random-effects models. We choose RE models when null hypothesis: preferred model, i.e., the Random-effects is not rejected. Robust standard errors in parentheses. ${ }^{*} p<0.1,{ }^{* *} p<0.05,{ }^{* * *} p<0.01$ 
Table A3. Random and Fixed-effects of Land and Livelihoods on Purchased Foods among Landowning Households.

\begin{tabular}{|c|c|c|c|c|c|c|}
\hline & $(1)$ & (2) & (3) & (4) & (5) & (6) \\
\hline $\begin{array}{l}\text { Dependent variable: Proportion of purchased } \\
\text { food: }\end{array}$ & $\begin{array}{c}\text { All types } \\
\text { of food } \\
\text { [RE] }\end{array}$ & $\begin{array}{c}\text { Tubers \& } \\
\text { cereals } \\
\text { [RE] }\end{array}$ & $\begin{array}{c}\text { Fruits, } \\
\text { vegetables, } \\
\text { and pulses } \\
\text { [RE] }\end{array}$ & $\begin{array}{l}\text { Eggs } \\
{[\mathrm{RE}]}\end{array}$ & $\begin{array}{l}\text { Milk \& } \\
\text { dairy } \\
\text { products } \\
\text { [FE] }\end{array}$ & $\begin{array}{c}\text { Meat \& } \\
\text { fish } \\
\text { [RE] }\end{array}$ \\
\hline \multicolumn{7}{|l|}{ Reference category: Own $<1.25$ acres } \\
\hline Own $1.25-5$ acres & $\begin{array}{l}-0.001 \\
(0.013)\end{array}$ & $\begin{array}{l}0.019 \\
(0.030)\end{array}$ & $\begin{array}{l}-0.021 * \\
(0.013)\end{array}$ & $\begin{array}{l}-0.053 \\
(0.034)\end{array}$ & $\begin{array}{l}-0.058 \\
(0.067)\end{array}$ & $\begin{array}{r}-0.034 \\
(0.029)\end{array}$ \\
\hline Own $>5$ acres & $\begin{array}{r}-0.017 \\
(0.019)\end{array}$ & $\begin{array}{l}0.044 \\
(0.042)\end{array}$ & $\begin{array}{c}-0.068^{* * *} \\
(0.020)\end{array}$ & $\begin{array}{l}-0.056 \\
(0.054)\end{array}$ & $\begin{array}{l}-0.106 \\
(0.089)\end{array}$ & $\begin{array}{r}-0.031 \\
(0.045)\end{array}$ \\
\hline Number of crops produced in the last 12 months & $\begin{array}{c}-0.040^{* * *} \\
(0.006)\end{array}$ & $\begin{array}{c}-0.099^{* * *} \\
(0.013)\end{array}$ & $\begin{aligned}-0.034^{* * *} & (0.006)\end{aligned}$ & $\begin{array}{c}-0.059 \\
* * * \\
(0.016)\end{array}$ & $\begin{array}{l}0.032 \\
(0.021)\end{array}$ & $\begin{aligned} &-0.031 \\
&(0.014)\end{aligned}$ \\
\hline Own livestock in the last 12 months & $\begin{array}{c}-0.044^{* * *} \\
(0.012)\end{array}$ & $\begin{array}{l}-0.059 * * \\
(0.028)\end{array}$ & $\begin{array}{r}-0.002 \\
(0.012)\end{array}$ & $\begin{array}{c}0.084 \\
* * * \\
(0.033)\end{array}$ & $\begin{array}{l}-0.158^{* * *} \\
(0.045)\end{array}$ & $\begin{array}{l}-0.003 \\
(0.027)\end{array}$ \\
\hline $\begin{array}{l}\text { Have at least } 1 \text { member aged } 15-64 \text { involved in } \\
\text { non-farm work }\end{array}$ & $\begin{array}{c}0.017 \\
(0.012)\end{array}$ & $\begin{array}{c}0.029 \\
(0.027)\end{array}$ & $\begin{array}{r}-0.001 \\
(0.011)\end{array}$ & $\begin{array}{c}0.064 \\
* * \\
(0.028)\end{array}$ & $\begin{array}{r}-0.048 \\
(0.046)\end{array}$ & $\begin{array}{c}0.002 \\
(0.023)\end{array}$ \\
\hline Year dummy & Yes & Yes & Yes & Yes & Yes & Yes \\
\hline Household characteristics & Yes & Yes & Yes & Yes & Yes & Yes \\
\hline Hausman test: $p$-value & 0.154 & 0.227 & 0.294 & 0.282 & 0.012 & 0.876 \\
\hline Observations & 1220 & 1220 & 1220 & 1220 & 1220 & 1220 \\
\hline
\end{tabular}

Notes: RE and FE stand for Random- and Fixed-effects models. We choose RE models when null hypothesis: preferred model, i.e., the Random-effects is not rejected; FE otherwise. Robust standard errors in parentheses. ${ }^{*} p<0.1,{ }^{* *} p<0.05,{ }^{* * *} p<0.01$.

Table A4. Robustness Check: Testing for the Effect of Migration on the Relationship between the Land-livelihood and Child Nutritional Status.

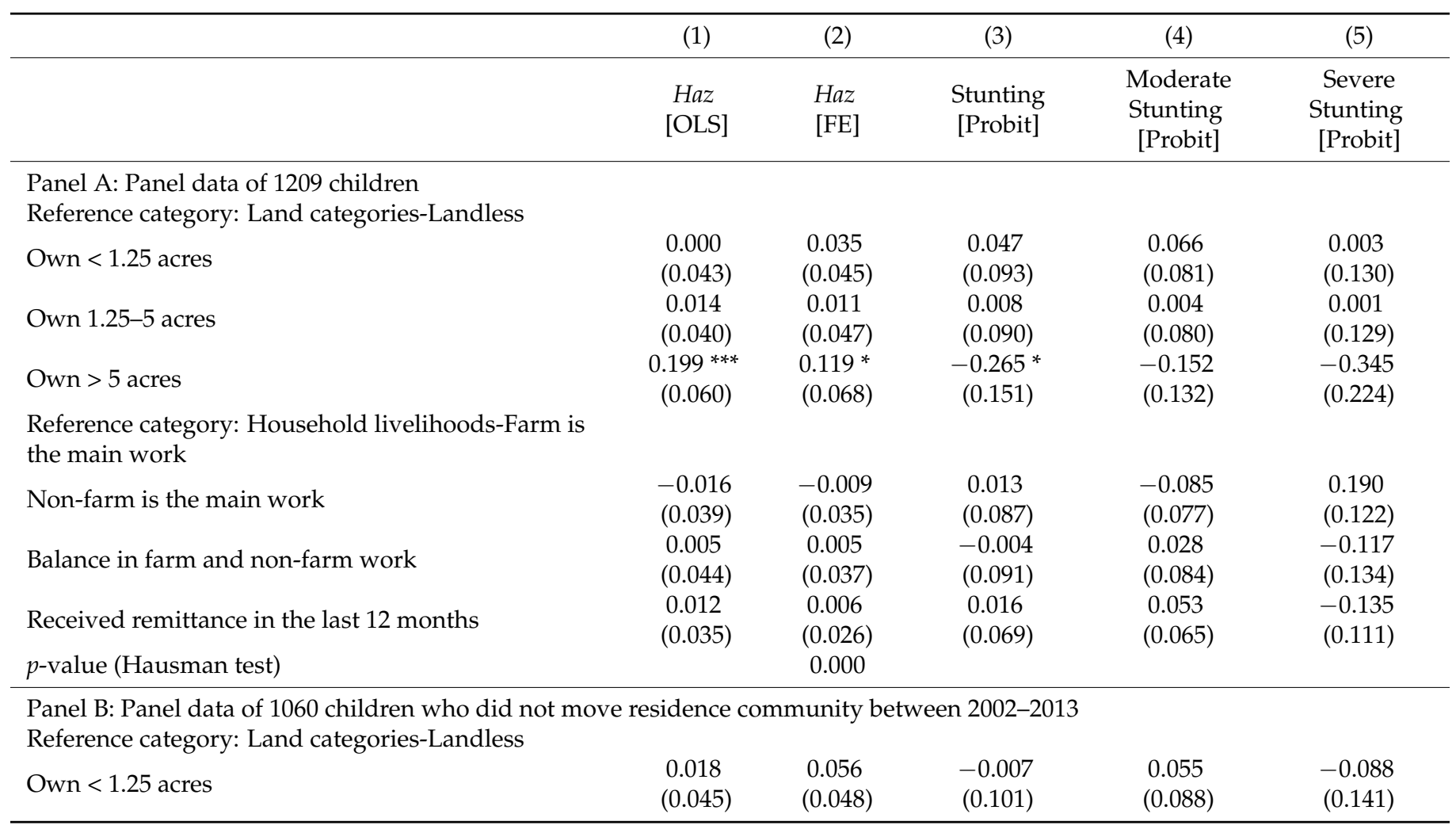


Table A4. Cont.

\begin{tabular}{|c|c|c|c|c|c|}
\hline & (1) & $(2)$ & (3) & $(4)$ & (5) \\
\hline & $\begin{array}{l}\mathrm{Haz} \\
\text { [OLS] }\end{array}$ & $\begin{array}{l}\mathrm{Haz} \\
{[\mathrm{FE}]}\end{array}$ & $\begin{array}{c}\text { Stunting } \\
\text { [Probit] }\end{array}$ & $\begin{array}{l}\text { Moderate } \\
\text { Stunting } \\
\text { [Probit] }\end{array}$ & $\begin{array}{c}\text { Severe } \\
\text { Stunting } \\
\text { [Probit] }\end{array}$ \\
\hline Own $1.25-5$ acres & $\begin{array}{l}0.065 \\
(0.043)\end{array}$ & $\begin{array}{l}0.031 \\
(0.052)\end{array}$ & $\begin{array}{r}-0.092 \\
(0.098)\end{array}$ & $\begin{array}{r}-0.061 \\
(0.087)\end{array}$ & $\begin{array}{l}-0.079 \\
(0.141)\end{array}$ \\
\hline Own $>5$ acres & $\begin{array}{c}0.246^{* * *} \\
(0.063)\end{array}$ & $\begin{array}{r}0.158^{* *} \\
(0.072)\end{array}$ & $\begin{array}{c}-0.351^{* *} \\
(0.159)\end{array}$ & $\begin{array}{r}-0.184 \\
(0.139)\end{array}$ & $\begin{array}{c}-0.487^{* *} \\
(0.238)\end{array}$ \\
\hline \multicolumn{6}{|c|}{$\begin{array}{l}\text { Reference category: Household livelihoods-Farm is } \\
\text { the main work }\end{array}$} \\
\hline Non-farm is the main work & $\begin{array}{r}-0.014 \\
(0.042)\end{array}$ & $\begin{array}{r}-0.007 \\
(0.038)\end{array}$ & $\begin{array}{l}0.026 \\
(0.092)\end{array}$ & $\begin{array}{r}-0.064 \\
(0.082)\end{array}$ & $\begin{array}{l}0.179 \\
(0.129)\end{array}$ \\
\hline Balance in farm and non-farm work & $\begin{array}{r}-0.005 \\
(0.048)\end{array}$ & $\begin{array}{l}0.015 \\
(0.040)\end{array}$ & $\begin{array}{l}0.039 \\
(0.101)\end{array}$ & $\begin{array}{l}0.069 \\
(0.093)\end{array}$ & $\begin{array}{r}-0.120 \\
(0.148)\end{array}$ \\
\hline Received remittance in the last 12 months & $\begin{array}{l}0.002 \\
(0.037)\end{array}$ & $\begin{array}{l}0.002 \\
(0.027)\end{array}$ & $\begin{array}{l}0.021 \\
(0.074)\end{array}$ & $\begin{array}{c}0.043 \\
(0.069)\end{array}$ & $\begin{array}{r}-0.091 \\
(0.115)\end{array}$ \\
\hline$p$-value (Hausman test) & & 0.000 & & & \\
\hline
\end{tabular}

Notes: We include time dummies, households', caregivers', children's characteristics and effects of the 2002 drought as controls in the analysis. FE stands for Fixed-effects. We choose FE models when null hypothesis: preferred model, i.e., the Random-effects is rejected. OLS and FE models reports coefficients, while Probit model reports the marginal effects. Robust standard errors in parentheses. ${ }^{*} p<0.1$, ${ }^{* *} p<0.05,{ }^{* * *} p<0.01$.

Table A5. Robustness Check: Testing for Attrition Problem.

\begin{tabular}{|c|c|c|c|c|}
\hline & $(1)$ & $(2)$ & (3) & $(4)$ \\
\hline Variables & $\begin{array}{l}\mathrm{Haz} \\
{[\mathrm{OLS}]}\end{array}$ & $\begin{array}{l}\text { Stunting } \\
\text { [Probit] }\end{array}$ & $\begin{array}{l}\text { Moderate stunting } \\
\text { [Probit] }\end{array}$ & $\begin{array}{c}\text { Severe stunting } \\
\text { [Probit] }\end{array}$ \\
\hline \multicolumn{5}{|c|}{ Reference category: Land categories-Landless } \\
\hline Own $<1.25$ acres & $\begin{array}{l}0.001 \\
(0.041)\end{array}$ & $\begin{array}{l}0.013 \\
(0.017)\end{array}$ & $\begin{array}{l}0.027 * \\
(0.016)\end{array}$ & $\begin{array}{r}-0.015 \\
(0.011)\end{array}$ \\
\hline Own $1.25-5$ acres & $\begin{array}{l}0.014 \\
(0.038)\end{array}$ & $\begin{array}{l}0.007 \\
(0.016)\end{array}$ & $\begin{array}{r}-0.002 \\
(0.015)\end{array}$ & $\begin{array}{l}0.007 \\
(0.009)\end{array}$ \\
\hline Own $>5$ acres & $\begin{array}{c}0.196^{* * *} \\
(0.057)\end{array}$ & $\begin{array}{l}-0.060 * * \\
(0.026)\end{array}$ & $\begin{array}{l}-0.029 \\
(0.024)\end{array}$ & $\begin{array}{l}-0.035^{* *} \\
(0.017)\end{array}$ \\
\hline \multicolumn{5}{|l|}{$\begin{array}{l}\text { Reference category: Household } \\
\text { livelihoods-Farm is the main work }\end{array}$} \\
\hline Non-farm is the main work & $\begin{array}{l}0.007 \\
(0.036)\end{array}$ & $\begin{array}{r}-0.004 \\
(0.016)\end{array}$ & $\begin{array}{c}-0.026^{*} \\
(0.015)\end{array}$ & $\begin{array}{r}0.023 * * \\
(0.009)\end{array}$ \\
\hline Balance in farm and non-farm work & $\begin{array}{l}-0.008 \\
(0.042)\end{array}$ & $\begin{array}{l}0.003 \\
(0.018) \\
\end{array}$ & $\begin{array}{l}0.002 \\
(0.017)\end{array}$ & $\begin{array}{r}-0.001 \\
(0.011)\end{array}$ \\
\hline Observations & 5622 & 5622 & 5622 & 5622 \\
\hline
\end{tabular}

Notes: We include time dummies, households', caregivers', children's characteristics and effects of the 2002 drought in the analysis. OLS estimate reports the coefficients, while Probit model reports the marginal effects. Robust standard errors in parentheses. ${ }^{*} p<0.1$, $^{* *} p<0.05$, *** $p<0.01$.

\section{References}

1. Herforth, A.; Bai, Y.; Venkat, A.; Mahrt, K.; Ebel, A.; Masters, W. Cost and Affordability of Healthy Diets across and within Countries. Background Paper for the State of Food Security and Nutrition in the World 2020; Global Food Security; FAO: Rome, Italy, 2020.

2. World Food Program. Global Report on Food Crises; United National World Food Program: Rome, Italy, 2019.

3. Goli, S.; Rammohan, A.; Reddy, S. The interaction of household agricultural landholding and caste on food security in Uttar Pradesh, India. Food Secur. 2021, 13, 219-237. [CrossRef]

4. Kadiyala, S.; Harris, J.; Headey, D.; Yosef, S.; Gillespie, S. Agriculture and nutrition in India: Mapping evidence to pathways. Ann. N. Y. Acad. Sci. 2014, 1331, 43-56. [CrossRef] [PubMed]

5. Rai, R.K.; Kumar, S.; Sekher, M.; Pritchard, B.; Rammohan, A. A life-cycle approach to food and nutrition security in India. Public Health Nutr. 2014, 18, 944-949. [CrossRef] [PubMed]

6. Tschirley, D.L.; Weber, M.T. Food security strategies under extremely adverse conditions: The determinants of household income and consumption in rural Mozambique. World Dev. 1994, 22, 73-159. [CrossRef] 
7. Rammohan, A.; Pritchard, B. The Role of Landholding as a Determinant of Food and Nutrition Insecurity in Rural Myanmar. World Dev. 2014, 64, 597-608. [CrossRef]

8. Government of India. Household Ownership and Operational Holdings in India; Government of India: New Delhi, India, 2013.

9. Khanal, A.R.; Mishra, A.K. Enhancing food security: Food crop portfolio choice in response to climatic risk in India. Glob. Food Secur. 2017, 12, 22-30. [CrossRef]

10. Pritchard, B.; Rammohan, A.; Sekher, M. Land ownership, agriculture, and household nutrition: A case study of north Indian villages. Geogr. Res. 2016, 55, 180-191. [CrossRef]

11. Pritchard, B.; Rammohan, A.; Sekher, M.; Parasuraman, S. Feeding India: Livelihoods, Entitlements and Capabilities; Routledge: London, UK, 2013.

12. Rais, M.; Pazderka, B.; VanLoon, G.W. Agriculture in Uttarakhand, India-Biodiversity, Nutrition, and Livelihoods. J. Sustain. Agric. 2009, 33, 319-335. [CrossRef]

13. Rao, N. Land rights, gender equality and household food security: Exploring the conceptual links in the case of India. Food Policy 2006, 31, 180-193. [CrossRef]

14. D'Souza, A.; Mishra, A.K.; Hirsch, S. Enhancing food security through diet quality: The role of nonfarm work in rural India. Agric. Econ. 2019, 51, 95-110. [CrossRef]

15. Himanshu; Lanjouw, P.; Murgai, R.; Stern, N. Non-Farm Diversification, Poverty, Economic Mobility and Income Inequality: A Case Study in Village India. Agric. Econ. 2013, 44, 461-473. [CrossRef]

16. Rammohan, A.; Vu, P. Gender Inequality in Education and Kinship Norms in India. Fem. Econ. 2018, 24, 142-167. [CrossRef]

17. Rammohan, A.; Pritchard, B.; Dibley, M.; Vicol, M. The links between agricultural production and the nutritional status of children in rural Myanmar. Food Secur. 2018, 10, 1603-1614. [CrossRef]

18. Pritchard, B.; Rammohan, A.; Vicol, M. The importance of non-farm livelihoods for household food security and dietary diversity in rural Myanmar. J. Rural. Stud. 2019, 67, 89-100. [CrossRef]

19. IIPS \& ICF. National Family Health Survey (NFHS-4), 2015-16: India (Factsheets); International Institute for Population Sciences: Mumbai, India, 2017.

20. Holland, C.; Rammohan, A. Rural women's empowerment and children's food and nutrition security in Bangladesh. World Dev. 2019, 124, 104648. [CrossRef]

21. Shively, G.; Sununtnasuk, C. Agricultural Diversity and Child Stunting in Nepal. J. Dev. Stud. 2015, 51, 1078-1096. [CrossRef]

22. Babatunde, R.O.; Qaim, M. Impact of off-farm income on food security and nutrition in Nigeria. Food Policy 2010, 35, 303-311. [CrossRef]

23. Owusu, V.; Abdulai, A.; Abdul-Rahman, S. Non-farm work and food security among farm households in Northern Ghana. Food Policy 2011, 36, 108-118. [CrossRef]

24. Lanjouw, P.; Quizon, J.; Sparrow, R. Non-agricultural earnings in peri-urban areas of Tanzania: Evidence from household survey data. Food Policy 2001, 26, 385-403. [CrossRef]

25. Block, S.; Webb, P. The dynamics of livelihood diversification in post-famine Ethiopia. Food Policy 2001, 26, 333-350. [CrossRef]

26. Parappurathu, S.; Kumar, A.; Bantilan, M.C.S.; Joshi, P.K. Food consumption patterns and dietary diversity in eastern India: Evidence from village level studies (VLS). Food Secur. 2015, 7, 1031-1042. [CrossRef]

27. Rahman, A.; Mishra, S. Does Non-farm Income Affect Food Security? Evidence from India. J. Dev. Stud. 2019, 56, 1190-1209. [CrossRef]

28. Humphries, D.L.; Dearden, K.A.; Crookston, B.T.; Fernald, L.C.; Stein, A.D.; Woldehanna, T.; Penny, M.E.; Behrman, J.R. CrossSectional and Longitudinal Associations between Household Food Security and Child Anthropometry at Ages 5 and 8 Years in Ethiopia, India, Peru, and Vietnam. J. Nutr. 2015, 145, 1924-1933. [CrossRef] [PubMed]

29. Humphries, D.L.; Dearden, K.A.; Crookston, B.T.; Woldehanna, T.; Penny, M.E.; Behrman, J.R. Household food group expenditure patterns are associated with child anthropometry at ages 5, 8 and 12 years in Ethiopia, India, Peru and Vietnam. Econ. Hum. Biol. 2017, 26, 30-41. [CrossRef] [PubMed]

30. Singh, A.; Park, A.; Dercon, S. School Meals as a Safety Net: An Evaluation of the Midday Meal Scheme in India. Econ. Dev. Cult. Chang. 2014, 62, 275-306. [CrossRef]

31. Kumra, N. An Assessment of the Young Lives Sampling Approach in Andhra Pradesh, India; Oxford University: London, UK, 2008.

32. WHO Multicentre Growth Reference Study Group. WHO Child Growth Standards based on length/height, weight and age. Acta Paediatr. Suppl. 2006, 450, 76-85.

33. Coates, J.; Swindale, A.; Bilinsky, P. Household Food Insecurity Access Scale (HFIAS) for Measurement of Food Access: Indicator Guide; Food and Nutrition Technical Assistance Project; Academy for Educational Development: Washington, DC, USA, 2007.

34. Thorat, S.; Neuman, K.S. (Eds.) Blocked by Caste: Economic Discrimination in Modern India; Oxford University Press: Oxford, UK, 2010.

35. Narsaiah, M. Indira Kranthi Patham a Poverty Eradication Programme in Yadadri Bhongir District of Telangana: A study. Int. J. Multidiscip. Educ. Res. 2019, 8, 148.

36. Rah, J.; Cronin, A.; Badgaiyan, B.; Aguayo, V.; Coates, S.; Ahmed, S. Household sanitation and personal hygiene practices are associated with child stunting in rural India: A cross-sectional analysis of surveys. BMJ Open 2015, 5, e005180. [CrossRef] [PubMed] 
37. Spears, D. How Much International Variation in Child Height Can Sanitation Explain? World Bank Policy Research Working Paper; Policy Research Working Papers; The World Bank: Washington, DC, USA, 2013; pp. 1-53.

38. Kanjilal, B.; Mazumdar, P.; Mukherjee, M.; Rahman, M.H. Nutritional status of children in India: Household socio-economic condition as the contextual determinant. Int. J. Equity Health 2010, 9, 19. [CrossRef] [PubMed]

39. Cumming, O.; Cairncross, S. Can water, sanitation and hygiene help eliminate stunting? Current evidence and policy implications. Matern. Child Nutr. 2016, 12, 91-105. [CrossRef]

40. Birner, R.; Gupta, S.; Sharma, N. The Political Economy of Agricultural Policy Reform in India: Fertilizers and Electricity for Irrigation; International Food Policy Research Institute: Washington, DC, USA, 2011; p. 231.

41. Pingali, P.; Aiyar, A.; Abraham, M.; Rahman, A. Rural livelihood challenges: Moving out of agriculture. In Transforming Food Systems for a Rising India; Palgrave Macmillan: Cham, Switzerland, 2019; pp. 47-71.

42. Bhavnani, R.R.; Lacina, B. Fiscal Federalism at Work? Central Responses to Internal Migration in India. World Dev. 2017, 93, 236-248. [CrossRef]

43. Kumar, N.; Harris, J.; Rawat, R. If they grow it, will they eat and grow? Evidence from Zambia on agricultural diversity and child undernutrition. J. Dev. Stud. 2015, 51, 1060-1077. [CrossRef]

44. Choithani, C. Understanding the linkages between migration and household food security in India. Geogr. Res. 2017, 55, 192-205. [CrossRef]

45. Deshingkar, P.; Start, D. Seasonal Migration for Livelihoods in India: Coping, Accumulation and Exclusion; Overseas Development Institute: London, UK, 2003. 